SPECIJALNI ČLANAK

\section{Medikalizacija u društvu i psihijatriji}

Moderna medicina ima nekoliko specifičnih karakteristika koje daju osnovni pečat događajima u savremenoj praksi.

Koncept EBM (engl. Evidence Based Medicine - Medicina zasnovana na dokazima) je naučno-tehnički pristup zasnovan na eksperimentalnim dokazima iz randomiziranih kliničkih studija i na Preporukama koje izdaju nacionalna i supranacionalna profesionalna udruženja. One (još) nemaju snagu zakonskih propisa, ali od toga nije daleko.

Specijalizacije i subspecijalizacije koje jesu potrebne, ali razbijaju celinu čoveka.

Biologizacija - je trend da se čovek tretira kao skup fizioloških i patofizioloških procesa lišen psiholoških sadržaja i društvene, socijalne komponente.

Medikalizacija - trend koji se najkraće može opisati kao pomeranje granica sa zdravlja na bolest; što je glavna tema ovog teksta.

Tehnologizacija - se ogleda u rastućoj dominaciji novih high tech aparata, i njihova agresivna primena ne samo u kliničkim centrima, već i u malim privatnim ordinacijama. Kao da bolesnik lekaru i nije potreban da bi postavio dijagnozu i odredio terapiju - toliko dominiraju slike i brojevi koji izlaze iz aparata.

Kriza inventivnosti u nauci i industriji, nemoć rešavanja najtežih problema medicine: mentalne bolesti, demencija, rak, ateroskleroza, astma, reumatizam ...

Alternativna medicina - koja naglo raste zbog slabosti naučne, iako to nije jedini razlog.

\section{Medikalizacija života}

Farmaceutska Industrija tzv. BigPharma je izgubila kreativnu snagu u pronalasku novih lekova krajem 20. veka, nove izvore profita traži na drugoj strani, u otvaranju novih tržišta za postojeće, što je dovelo do stanja koje se danas opisuje kao medikalizacija života. Frustrirana neuspelim pokušajima da se nađu efikasni lekovi za teške masovne bolesti kao rak i demencija, Industrija se okrenula širenju granica bolesti nalazeći sebi jake saveznike u Medicini i Medijima. ${ }^{1}$

\section{Tomislav Kažić}

Beograd, Srbija

\section{Korespondencija}

Prof. dr Tomislav Kažić

tkazic@eunet.rs
U nemoći da nađe lek za svaku bolest - Pill for every ill, obratila se za pomoć Medicini koja neumorno proizvodi nove dijagnoze, nove faktore rizika i snižava granične vrednosti za postojeće, kako bi farmaceutska industrija oličena $u$ sintagmi BigPharma mogla da ima bolest za svaki lek koji proizvede - Ill for every pill.

Tako se Trojna Alijansa: Industrija, Medicina, Mediji okrenula zdravim ljudima kao potrošačima, eksploatišući njihove blage i prolazne tegobe ili neumitne fiziološke promene u mladosti ili u starosti, njihove strahove i želje.

Kompletna procedura je usavršena. Mediji najpre objavljuju seriju priča usmerenih da razviju strah od stanja ili tegobe, i da skrenu pažnju na nove terapijske mogućnosti. Onda dolaze "nezavisni" medicinski eksperti (tzv. opinion leaders) prehodno motivisani i stumulisani od strane Industrije, da objašnjavaju suštinu i težinu problema ako se ne leči i dobrobiti od lečenja. Grupe potrošača ili novinariistraživači dovode pred kamere "žrtve", a onda dolazi marketing Industrije da prikaže asortiman. ${ }^{2}$ Princip je isti, sve su ostalo nijanse.

Medikalizacija je dobro zahvatila sve periode ljudskog veka od rođenja do smrti, kao i sve grane medicine, mada ne sve podjednako.

\section{Medikalizacija u psihijatriji}

Psihijatrija je velika oblast za medicinske i farmakoterapijske intervencije, te je sasvim razumljivo da je obilato iskorišćena za razne vidove medikalizacije. Posebnu pogodnost za to pružaju male i nejasno definisane granice između zdravlja i mentalne bolesti. Ovde se ukazuje na nekoliko nezaobilaznih primera.

Novi dijagnostički entiteti - U psihijatriji se broj dijagnostičkih kategorija u DSM (Diagnostic and Statistical Manual) Američkog udruženja psihijatara (po kojem se svi ravnaju) povećao sa 16 do 1941. na 106 u DSM-I 1952., i na 357 u DSM-IV $1994 .{ }^{3}$ Sve je to trebalo prikazati - naravno uz podršku statistike - kao opasna stanja koja treba svakako lečiti, kratkoročno, dugoročno ili doživotno. To je neizbežno stvorilo nove milione bolesnika od shizofrenije i depresivnih sindroma, i recepata za nove atipične antipsihotike i SSRI antidepresive. A kako i ne bi kad se - prema 
jednoj analizi iz SAD - samo u periodu 1972-1988. njihov broj povećao za 3 odnosno 4 puta. ${ }^{4}$

Nove populacije bolesnika - Pod jakim pritiskom Industrije, registruju se nagle promene u prevalenci bolesti u neuropsihijatriji:

- poremećaji pažnje kod dece (ADHD) su u porastu, dostižu 20\% u nekim regionima;

- poremećaji pažnje kod odraslih u SAD je narastao do 3. psihijatrijske dijagnoze, posle depresije i alkoholizma;

- depresija kod dece postaje često neprepoznat problem koji treba lečiti;

- premenstrualni sindrom (PMS) se registruje kod čak $75 \%$ mladih žena;

- premenstrualni disforički sindrom (PMDD) se izdvaja u posebni entitet da bi se propisivali antidepresivi;

- prerana ejakulacije od koje navodno pati 33\% seksualno aktivnih muškaraca zahteva specifičnu terapiju;

- erektilna disfunkcija navodno prisutna kod skoro 50\% muškaraca je dobila nove efikasne lekove;

- sindrom nemirnih nogu se konstatuje kod 5-10\% odraslih osoba, postaje sve aktuelnija tema za članke i simpozijume.

Nove indikacije za SSRI antidepresive - Pojava fluoksetina (Prozac), prvog selektivnog inhibitora preuzimanja serotonina (engl. Selective Serotonin Reuptake Inhibitor - SSRI), njegova jaka promocija u američkim medijima, doneli su ogromne profite i mnogo izmenili predstave o mentalnom zdravlju i bolesti. Na talasima medijske promocije, Prozac i drugi SSRI su od moćnog udruženja APA (American Psychiatric Association) favorizovani kao lekovi za zabrinute, uplašene, tužne, opsednute, stidljive i na drugi način potištene i uznemirene Amerikanke i Amerikance. Da li su ih urećili kao što se priča, to nije izvesno, ali da su usrećili Industriju kojoj kao 'blockbuster drugs' donose milijarde dolara - to je sasvim sigurno.

Propisivanje SSRI počelo je 1990 ih kod depresije, a 2009. se oni propisuju cak kod 12 depresivnih i anksioznih entiteta: depresija, depresija sa anksioznošću, depresija za prevenciju recidiva, opsesivno-kompulzivni poremećaj opsesivnokompulzivni poremećaj za prevenciju recidiva, panični poremećaj, panični poremećaj za prevenciju recidiva, socijalna fobija, generalizovana anksioznost, bulimija i PMDD.

Stidljivost - Promocija bolesti - Na primeru bezazlenog poremećaja ili samo varijeteta normalnog ponašanja se jasno demonstrira metodologija medikalizacije: ${ }^{5}$

- $\quad$ 1980. stidljivost debituje kao retka bolest social phobia (socijalna fobija),

- 1994. postaje izuzetno česta bolest kao social anxiety disorder, a

- 1999. social anxiety disorder postaje teško stanje $u$ medicini tj. a severe medical condition; i sve to samo da bi se povećala prodaja preparata Paxil (GSK).
Udar na psihu dece i omladine - Deca i omladina čine znatan deo populacije, ali kao prirodno zdravi nisu dovoljno iskorišćeni kao potrošači lekova. Druge industrije su davno pretekle BigPharmu u eksploataciji njihovog potrošačkog potencijala. Da se to nekako popravi, i u oblast psihijatrije su nedavno definisane dve nove dijagnoze, indikacije.

Pedijatrijska anksioznost se opisuje kao kompleksni poremećaj: generalizovana + anksioznost zbog razdvajanja + socijalna fobija - sa prevalencom od 6-20\%, koji treba lečiti kombinacijom sertralina i kognitivnom terapijom.

Bipolarna depresija se dijagnostikuje kod dece od 2 godine i starije, i te male bolesnike je šef psihofarmakologije na Harvardu počeo lečiti koktelom lekova od kojih nijedan nije bio odobren za decu do 10 godina. Inače u toku je velika epidemija bipolarne bolesti kod dece, a u periodu 1994-2003. se broj bolesnih sa tom dijagnozom povećao 4 puta ${ }^{6}$

Kako će na sve to reagovati socijalna psihijatrija, udruženja roditelja i društvo u celini ostaje da se prati.

Udar na stare i nemoćne - Uznemirenost dementnih osoba jeste realno veliki problem, i za njega postoje definisani protokoli koji uključuju i imobilizaciju i primenu nekih psihofarmaka. Međutim, način na koji je pod pritiskom Industrije rešavan u Velikoj Britaniji, imao je katastrofalne posledice. Izgleda apsurdno da se i u zemlji inače racionalnih Engleza moralo čekati da one postanu katastrofalne da bi dospele u javnost, ali kapital ne zna za nacije i granice.

Zbog propisivanja velikih doza novih atipičnih antipsihotika kod 150.000 bolesnika sa Alzheimerovom bolešću i drugim oblicima demencije - protivno preporukama NICE (engl. National Institite of Clinical Exelence) - prouzrokovano je preko 2.000 smrtnih ishoda i 1.620 nefatalnih šlogova. Ministar zdravlja se odmah (novembra 2009.) obratio javnosti i na TV izjavio da je to neprihvatljivo, da se to mora smanjiti, mada "neće moći preko noći".

Propisivanje lekova za neodobrene indikacije - U ovoj oblasti je eklatantan primer lek gabapentin tj. preparat Neurontin; naglasak je na Neurontin, jer u SAD postoje propisi koji dozvoljavaju reklamiranje u medijima i lekova koji se propisuju na recept.

Primarna indikacija za ovaj lek je bila: Parcijalni napadi epilepsije rezistentni na konvencionalnu terapiju. Međutim, kako je vreme odmicalo dodavane su nove indikacije i sve šire: Neurontin kao monoterapija, NEURontin za bipolarnu depresiju, Neurontin za neuralgije, NeUrontin za dijabetesnu polineuropatiju, Neurontin za bolove, NEURONTIN za sve! Tako je Neurontin postao blockbuster, tj. zaradio 2.7 milijarde dolara u 2003. Sledeće godine je Pfizer 
platio 430 miliona za obustavu krivičnog postupka zbog nezakonskog marketinga, ali to je cena uspešnog biznisa najvećeg među najvećima, a NeURonTIN se i dalje propisuje kao tonik za svaku priliku i donosi veliki profit. ${ }^{6,7}$

Ovom tekstu su dati primeri iz psihijatrije, za što ima više razloga - od kojih je možda najjači nedovoljan broj kvalitetnih randomiziranih kliničkih studija, te nedovoljan oslonac za promotivnu snagu EBM. Međutim, vrlo su ubedljivi argumenti za medikalizaciju i u kardiologiji, gde se samo sniženjem normalnih vrednosti krvnog pritiska i frakcija holesterola do apsurdno niskih nivoa iz populacije zdravih u populaciju bolesnika prebacuju desetine ili stotine miliona ljudi - a sve to radi povećanja inače visokih profita.

U vreme dok je pisan ovaj tekst odvijala se burna "pandemija" meksikanskog, svinjskog ili novog gripa, koja je dobro prikazala sve nivoe manipulacije bolešcu i lekovima, ukazujući da nikakve Preporuke ne oslobađaju lekara vlas- titih iskustava i odgovornosti za svakog bolesnika posebno, a najmanje kad su u sukobu sa zdravim razumom.

\section{Reference}

1. Kažić T. Lekovi i društvo. U Ćorić B (urednik), Čovek i Lek, Beograd 2004: 53-65.

2. Moynihan R, Heath I, Henry D. Selling sickness: the pharmaceutical industry and disease mongering. BMJ 2002; 324: 886-91.

3. Double D. The limits of psychatry. BMJ 2002; 324: 900-4.

4. Cohen D. Neuroleptic drug treatment in schizophrenia: The state of confusion. In D Cohen (editor), Challenging the therapeutic state, part two: Further disquisitions on the mental health system. J Mind Behav 1994; 15: 139-56.

5. Lane C. Shyness: How normal behaviour became a sickness. Yale University Press, 2008.

6. Angell A. Drug companies \& doctors: A story of corruption. NY Review of Books 2009, No 1, January 15.

7. Landefeld CS, Steinman MA. Neurontin - marketing through misinformation and manipulation. NEJM 2009; 360: 103-6. 